\title{
Sebuah Pengantar kepada Dekonstruksi
}

\author{
Chris Ruhupatty \\ cruhupatty@gmail.com
}

\begin{abstract}
This article is an introduction to deconstruction. It must be admitted that we cannot understand deconstruction fully. To be precise, we only can describe it by using the other word or text. That is why this article is just an introduction or just an-other way to say it. "Deconstruction" itself is a disclosure about the reality of the text. Text, says the tradition of West philosophy, is a representative of the world. Therefore, we can understand the world fully using texts. Jacques Derrida (1930-2004) the founder of deconstruction does not agree with that notion. For him, the word or text cannot describe the world fully. The text needs to be deconstructed in its ways to present the world. In this framework, Derrida shows us even "deconstruction" itself cannot be present using any words or texts.
\end{abstract}

\begin{abstract}
Abstrak
Artikel ini adalah sebuah pengantar kepada dekonstruksi. Harus diakui bahwa kita tidak dapat memahami apa itu dekonstruksi secara utuh. Tepatnya, kita hanya dapat menggambarkannya melalui kata atau teks yang-lain. Itulah mengapa artikel ini hanyalah sebuah pengantar atau hanya sebuah cara yang-lain untuk mengatakannya. "Dekonstruksi" itu sendiri adalah sebuah penyingkapan tentang realitas dari teks. Teks, sebagaimana dikatakan oleh tradisi filsafat Barat, adalah sebuah representasi dari dunia. Sebab itu, kita dapat memahami dunia secara utuh melalui teks. Jacques Derrida (1930-2004) pencetus dekonstruksi tidak setuju dengan gagasan itu. Baginya, kata atau teks tidak dapat menjelaskan dunia secara utuh. Teks perlu untuk didekonstruksi dalam usahanya untuk menjelaskan dunia. Dalam kerangka inilah, Derrida hendak menunjukkan kepada kita bahwa "dekonstruksi” itu sendiri tidak dapat dijelaskan menggunakan kata atau teks.
\end{abstract}

Keywords: dekonstruksi, différance, jejak, suplemen, Fenomenologi. 


\section{Pengantar}

Derrida memperkenalkan dekonstruksi secara umum, di luar Prancis, pada sebuah seminar di Johns Hopkins University, 21 Oktober 1966. Ia memperkenalkannya sebagai penyingkapan terhadap jerat metafisika kehadiran dalam seluruh tradisi pemikiran filsafat Barat. Ciri metafisika kehadiran yang dimaksudkan oleh Derrida adalah upaya yang dilakukan oleh filsafat Barat untuk menemukan kebenaran utuh dari realitas atau dunia. Dan kebenaran utuh tersebut, oleh Filsafat Barat, dinyatakan sebagai sebuah kehadiran yang disebut sebagai Being. Kenyataan tersebut telah memicu Derrida untuk melakukan peninjauan kembali terhadap keberadaan dari "kebenaran utuh" tersebut. Apakah kebenaran utuh itu benar-benar ada atau tidak ada?

Salah satu contoh yang dapat digunakan untuk menyelidiki keberadaan dari "kebenaran utuh" adalah perkembangan ilmu tentang manusia (antropologi) yang telah melahirkan cabang baru, yaitu: etnografi. Antropologi pada awalnya menjadikan budaya Eropa sebagai "pusat" dalam menemukan kebenaran utuh tentang manusia. Namun dalam perkembangannya kemudian, ternyata budaya Eropa telah digeser dari "pusat," sehingga membuka ruang bagi budaya-budaya non-Eropa untuk dijadikan sebagai "pusat" dalam memahami tentang manusia (etnografi). Kenyataan tersebut telah menyingkapkan sebuah kebenaran tentang keberadaan dari "kebenaran utuh" yang tidak lain adalah sebuah konstruksi manusia belaka. Dibangun berdasarkan tujuan tertentu atau dengan istilah lain bisa disebutkan sebagai: ekonomisasi. ${ }^{1}$

Penyingkapan keberadaan "kebenaran utuh" atau Being memberikan gambaran umum mengenai pemikiran filsafat Barat yang sekurang-kurangnya memiliki dua buah aliran besar, yaitu: (1) aliran filsafat yang berpijak pada keberadaan dari "kebenaran utuh" (Being), dan (2) aliran filsafat yang menolak keberadaan dari "kebenaran utuh" atau yang biasa dikenal sebagai nihilisme. Lalu, dimanakah posisi dekonstruksi?

\footnotetext{
${ }^{1}$ Derrida, Jacques (2001). Writing and Difference. Penerj. Alan Bass. London: Routledge Classics. h. 356-7.
} 
Dekonstruksi tidak dapat dimasukkan pada salah satu aliran pemikiran di atas. Dalam kerangka dekonstruksi, "kebenaran utuh" tidak lain adalah teks yang mengisi kekosongan atau kebutaan manusia dihadapan realitas atau dunia. Tanpanya, manusia tidak dapat memahami realitas atau dunia yang ada dihadapannya. Namun kekosongan tersebut telah diisi oleh teks yang membuat manusia dapat mengucapkan dan menuliskan realitas atau dunia agar dapat dikenali oleh logika. Dengan perkataan lain, kebenaran utuh atau teks tidak lain hanyalah sebuah permainan (play) untuk mengisi kekosongan atau kebutaan manusia terhadap dunia.

Derrida juga menyebut "permainan" ini sebagai suplemen. Namun, suplemen yang dimaksudkan disini bukanlah sesuatu yang berasal dari luar untuk mengisi atau menambahkan kekosongan yang ada. Karena jika demikian, maka suplemen pastilah merujuk pada kehadiran di luar teks, yaitu kehadiran dari sebuah "kebenaran utuh" yang berperan sebagai origin dari segala sesuatu (Being). Sedangkan suplemen yang dimaksudkan oleh Derrida mengisi atau menambahkan kekosongan dirinya sendiri, tanpa campur tangan dari sesuatu apapun di luar dirinya. ${ }^{2}$ Pendek kata, "kebenaran utuh" yang diklaim oleh tradisi filsafat Barat tidak lain adalah sebuah teks yang tidak berhubungan dengan suatu apapun di luar dirinya. Bahkan tidak ada kaitannya dengan realitas atau dunia. Teks hanya mengisi kekosongan dirinya sendiri.

Hal tersebut membedakan dekonstruksi dari seluruh pemikiran dalam tradisi filsafat Barat. Dekonstruksi tidak menerima keberadaan "kebenaran utuh" sebagai sebuah entitas di luar teks, dan secara bersamaan tidak menolak keberadaannya secara total sebagaimana terdapat pada nihilisme. Dekonstruksi menyingkapkan bahwa apa yang disebut sebagai "kebenaran utuh" dari dunia (Being) tidak lain adalah teks yang membantu manusia untuk mengucapkan dan menuliskan dunia agar dapat dikenali oleh logika.

Demikianlah sekilas mengenai dekonstruksi berdasarkan makalah yang disampaikan oleh Derrida di Johns Hopkins University (Structure, Sign, and Play, 1966). Subbahasan selanjutnya akan mengantar pada pengenalan terhadap dekonstruksi dengan

${ }^{2}$ Derrida, Jacques. Writing and Difference, 365-9. 
menggabungkan karya-karya Derrida lainnya dalam sistematika sebagai berikut: (1) Dunia di dalam Teks, (2) Dekonstruksi di dalam Teks, dan Kesimpulan.

\section{Dunia di dalam teks}

Derrida mengembangkan pemikiran filosofisnya dalam pengaruh Fenomenologi menurut pemikiran Edmund Husserl (1859-1938). Ditandai sejak ia memilih Fenomenologi sebagai topik dalam penulisan disertasinya pada tahun 1953-1954 yang kemudian terbit pada tahun 1990 dengan judul: "The Problem of Genesis in Husserl's Philosophy." Namun karyanya tentang Fenomenologi yang terbit pertama kali adalah: “Edmund Husserl's 'Origin of Geometry': An Introduction (1962) dan diulas kembali dalam Speech and Phenomena (1967). Tidak mengherankan jika kita dapat menemukan kesamaan yang bersifat fundamental di antara pemikiran Derrida dan pemikiran Husserl. Walaupun terdapat juga perbedaan yang mencolok di antara keduanya.

Persamaan dari pemikiran kedua filsuf ini dapat ditemukan di dalam ide tentang manusia yang berada di tengah dunia (ada-di-tengah-dunia). Derrida mengaminkan pemikiran Husserl tersebut dengan melakukan perubahan yang cukup radikal. Husserl yang menyatakan bahwa manusia berada di tengah dunia dengan tanda bahwa dunia memberikan telah dirinya kepada manusia melalui apa yang disebutnya sebagai tanda (sign). Namun Husserl membagi tanda menjadi dua, antara lain: (1) tanda yang memiliki makna, dan (2) tanda yang tidak memiliki makna. Pendek kata, di mata Husserl, manusia memiliki potensi untuk dapat memahami kebenaran utuh dari dunia. Sedangkan di mata Derrida, meskipun manusia berada di tengah dunia, tapi tetap saja manusia tidak mampu untuk memahami dunia secara utuh. Karena manusia mencerap dunia melalui panca indra dan pencerapan tersebut menghasilkan tanda atau teks yang dapat dikenali oleh logika. Maka, bagi Derrida, tanda atau teks bukanlah representasi utuh dari dunia. Melainkan sebuah representasi dari pengalaman indrawi dihadapan dunia. Atau dengan istilah lain, tanda atau teks dalam pemikiran Derrida tidak lebih dari sekadar metafora dari dunia. ${ }^{3}$ Alhasil, bagi Derrida, manusia tidak dapat

3 Derrida, Jacques (1973). Speech and Phenomena, Penerj. David Allison dan Newton Garner. Evanston: Northwestern University Press. h. 17-26. 
memahami dunia melalui tanda atau teks, karena terdapat jarak antara dunia pada dirinya sendiri dan dunia yang dipahami melalui tanda atau teks.

Maka jelas dengan sendirinya bahwa Derrida mengikuti pemikiran Husserl tentang dunia yang memberikan dirinya untuk dipahami oleh manusia. Hanya saja ia menolak pemikiran Husserl yang menyatakan bahwa manusia dapat menemukan kebenaran utuh tentang dunia secara jernih. Bahkan Husserl sendiri telah menyatakan bahwa telah menjadi tugas dari Fenomenologi untuk menyatakan dunia secara utuh atau jernih dengan cara kembali kepada halnya. Gagasan itu disampaikannya dengan menggunakan frasa dalam bahasa Jerman: Zurück zu den Sachen Selbst! (Inggris: we must go back to the "things themselves"). ${ }^{4}$ Dengan perkataan lain, Husserl secara lugas hendak mengatakan bahwa dunia atau halnya dapat dipahami secara utuh oleh manusia! Husserl pun menegaskan bahwa manusia telah terhubung dengan dunia atau halnya melalui ekspresi. Oleh karenanya, Husserl menempatkan ekspresi sebagai keutamaan atau origin dari bahasa. Sehingga pada mulanya adalah ekspresi yang yang mendahului bahasa. Berikut kutipan lengkapnya:

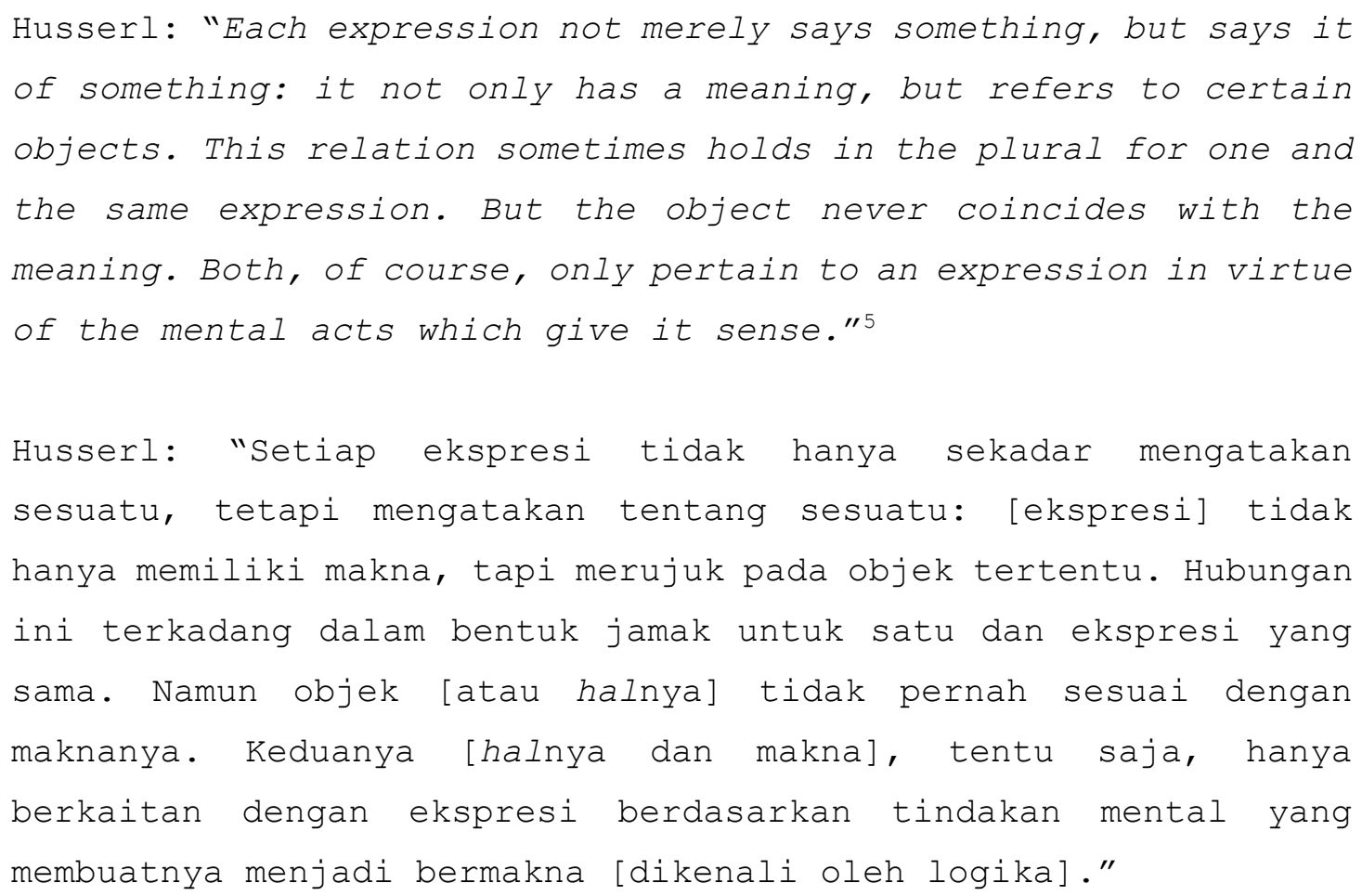

\footnotetext{
${ }^{4}$ Husserl, Edmund (2001). Logical Investigations Volume I. Penerj. J. N. Findlay. London dan New York: Routledge. h. 168.

${ }^{5}$ Husserl, Edmund. Logical Investigations Volume I. h. 197.
} 
Derrida memandang pemikiran Husserl tentang hubungan antara dunia atau halnya dan manusia melalui ekspresi telah menunjukkan sebuah upaya untuk keluar dari kenaifan pemikiran ontologi menurut tradisi filsafat Barat. Namun di saat bersamaan, lanjut Derrida, Husserl masih tetap berada dalam jerat metafisika kehadiran yang sama dengan filsafat Barat. Itu ditandai dengan menyatakan keberadaan dari kebenaran utuh dari dunia sebagai sebuah kehadiran di luar teks. Berikut kutipan lengkap dari tanggapan Derrida terhadap Husserl:

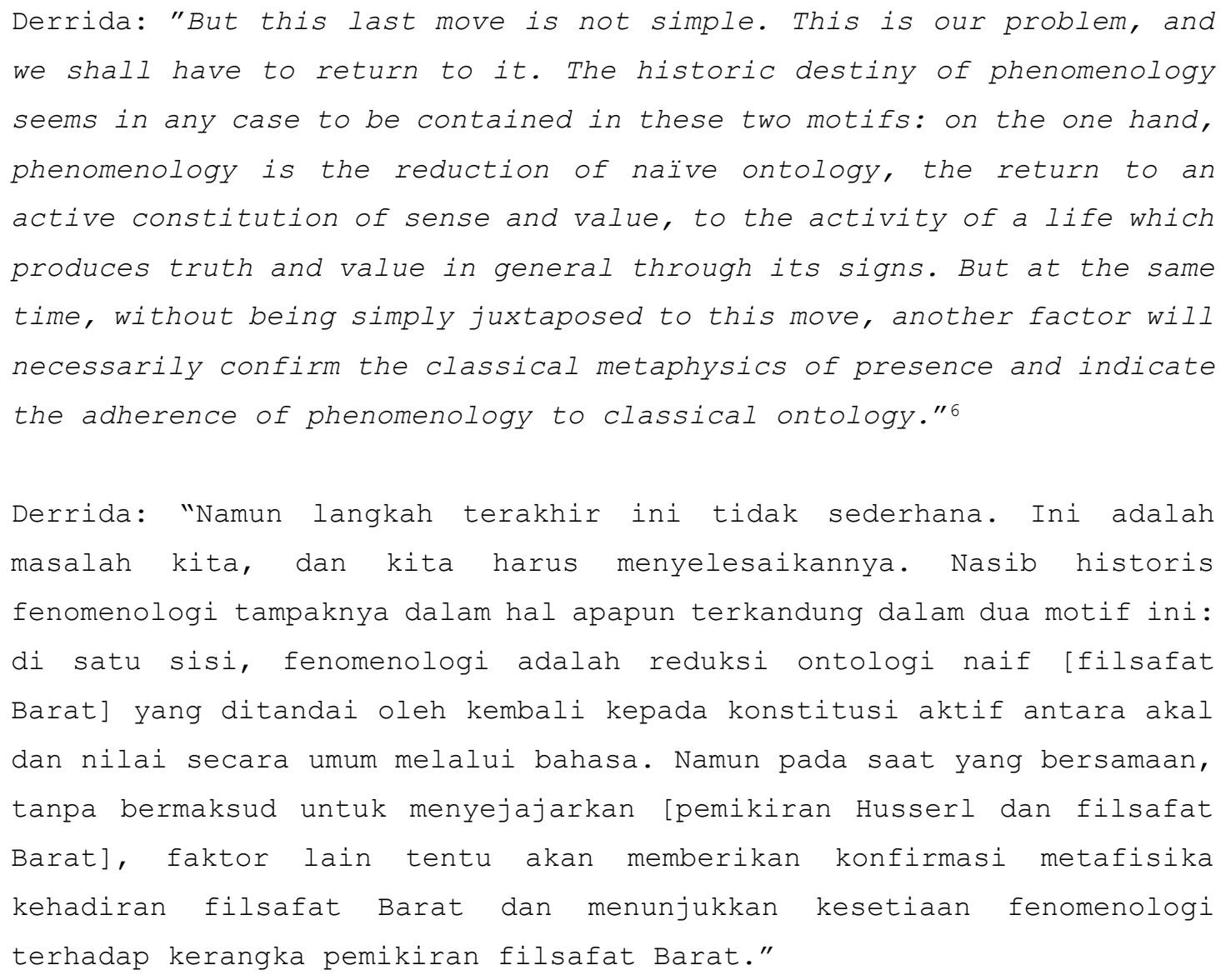

Maka, penolakan Derrida terhadap pemikiran Husserl mengenai kemungkinan manusia dapat memahami dunia secara utuh didasari oleh jerat metafisika kehadiran yang masih melekat pada pemikiran tersebut. Disamping itu, selain bersifat metafisika, tradisi pemikiran yang menyatakan kebenaran utuh sebagai sebuah kehadiran akan berujung pada kekerasan teks yang didasari atas klaim terhadap penemuan dunia secara utuh

${ }^{6}$ Derrida, Jacques. Speech and Phenomena, h. 25-6. 
(ideal). Kita dapat menemukan klaim penemuan dunia secara utuh (ideal) dalam pemikiran Husserl melalui analogi yang ia gunakan, yaitu: S adalah P. ${ }^{7}$

Bagi Derrida "S adalah P" menggambarkan sebuah ekspresi yang berasal dari luar atau pihak ketiga. Karena mustahil "S" menjelaskan tentang dirinya sendiri. ${ }^{8}$ Oleh karena itu, di mata Derrida, ekspresi menurut pemikiran Husserl niscaya terkondisikan bersifat metafisika. Cirinya adalah: menyatakan keberadaan dari kebenaran utuh tentang dunia sebagai sebuah kehadiran di luar teks yang memberikan dirinya untuk dipahami oleh logika manusia.

Patut untuk menjadi perhatian bahwa Derrida hanya melakukan penolakan terhadap "ekspresi" yang dinyatakan oleh Husserl sebagai media untuk menemukan dunia secara utuh. Karena Derrida menerima gagasan tentang “ekspresi” sebagai pencerapan indrawi yang mendahului teks, tapi di tangannya, "ekspresi” tidak dinyatakan sebagai origin dari teks tentang dunia yang utuh. Sehingga seolah-olah "ekspresi” mampu melampaui jarak antara dunia dan teks. Sebaliknya, menurut Derrida, seharusnya "ekspresi” adalah sebuah permainan dari penundaan terus-menerus terhadap dunia yang-utuh. Dan permainan dari penundaan yang dimaksudkan adalah différance. ${ }^{9}$ Pendek kata, "ekspresi" atau différance merupakan peristiwa (event) ${ }^{10}$ dari permainan penundaan makna dan permainan dari perbedaan teks tentang dunia. ${ }^{11}$ Alhasil, kita tidak dapat memiliki kebenaran utuh tentang dunia. Kita hanya memiliki dunia yang dapat dipahami oleh logika atau dunia di dalam teks yang selalu mengalami dekonstruksi.

Dengan demikian, dekonstruksi merupakan sebuah penyingkapan terhadap jerat metafisika kehadiran pada klaim tentang penemuan kebenaran utuh dari dunia di seluruh tradisi pemikiran filsafat Barat. Karena pada kenyataannya, manusia hanya mencerap dunia melalui indra. Dan hasil pencerapan tersebut dikonversi menjadi teks yang dapat dikenali oleh logika. Maka jelas dengan sendirinya bahwa terdapat jarak

\footnotetext{
${ }^{7}$ Bandingkan dengan Edmund Husserl, Logical Investigations Volume I, h. 198.

${ }^{8}$ Derrida, Jacques. Speech and Phenomena, h. 73-4.

${ }^{9}$ Derrida, Jacques. Speech and Phenomena, h. 102-3.

${ }^{10}$ Dipilih kata "peristiwa" (Inggris: event) untuk membedakannya dengan sebuah "tindakan." Karena dekonstruksi bukanlah sebuah "tindakan," tapi juga bukan sebuah kepasifan. Dekonstruksi ada di antara aktif dan pasif. Untuk itu "peristiwa" lebih tepat untuk digunakan.

11 Uraian khusus tentang différance dapat di baca di Jurnal Online Dekonstruksi vol. 1 http://jurnaldekonstruksi.id/index.php/dekonstruksi/article/view/24
} 
antara dunia yang ada dihadapan manusia di satu sisi dan dunia pada teks yang diucapkan dan dituliskan oleh manusia di sisi lainnya.

\section{Dekonstruksi di dalam teks}

Pada 10 Juli 1983 silam, Derrida menulis sebuah surat kepada Toshihiko Izutsu (19141993) yang berisikan penjelasan tentang dekonstruksi. Surat tersebut kemudian diterbitkan dengan judul: Letter to a Japanese Friend (Derrida and Différance, ed. David Wood dan Robert Bernasconi, 1998). Diskusi antara Derrida dan Izutsu mengambil topik tentang kemungkinan untuk menerjemahkan kata “dekonstruksi” ke dalam bahasa Jepang. Derrida mengakui bahwa itu bukanlah tugas yang mudah. Mengingat sudah terlalu banyak kekeliruan yang terjadi dalam hal memahami “dekonstruksi." Kekeliruan itu terjadi baik di Prancis, sebagai negara asal Derrida, maupun di negara-negara lainnya. Oleh sebab itu, Derrida mengambil kesempatan melalui diskusi ini untuk memberikan klarifikasi terhadap kekeliruan yang ada.

Pertama-tama Derrida menekankan bahwa “dekonstruksi” yang dimaksudkan tidak ada hubungannya dengan arti kata yang ditemukan di dalam kamus bahasa Prancis. ${ }^{12}$ Awalnya, kata "dekonstruksi” dipilih oleh Derrida dalam inspirasi pemikiran Martin Heidegger (1889-1976) tentang Destruktion atau Abbau (Being and Time). Namun kata dalam bahasa Prancis yang sepadan untuk menerjemahkan kata dalam bahasa Jerman: Destruktion atau Abbau, memiliki arti yang negatif, yaitu: menghancurkan atau meniadakan sesuatu. Kata dalam bahasa Prancis itu adalah: destruction. Arti kata destruction jelas berbeda dengan maksud yang hendak disampaikan oleh Heidegger, yaitu: penghancuran secara positif terhadap ontologi filsafat Barat.

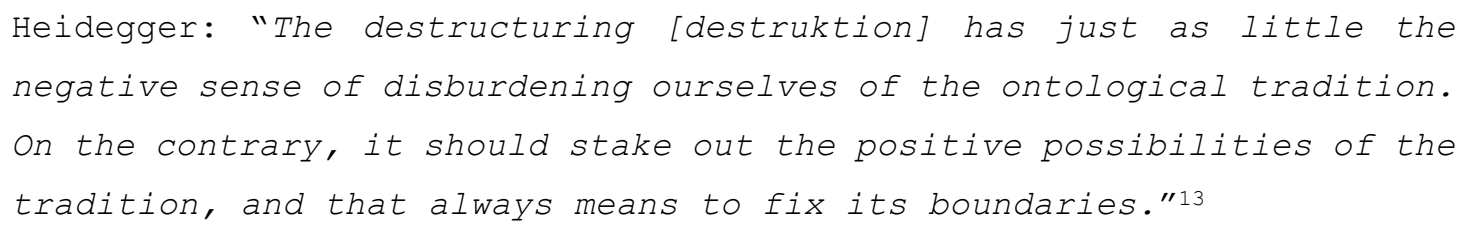

12 Bandingkan dengan Derrida, Jacques (1988). Letter to a Japanese Friend dalam Derrida and Différance. ed. David Wood dan Robert Bernasconi. Evanston: Northwestern University Press. h. 1 ${ }^{13}$ Heidegger, Martin (1996). Being and Time. Penerj. Joan Stambaugh. Albany: State University of New York Press. h. 20. 
Heidegger: Destruktion hanya memiliki sedikit muatan negatif untuk melepaskan diri kita dari tradisi ontologi [filsafat Barat]. Sebaliknya, ia harus menjaga kemungkinan positif dari tradisi [ontologi], dan memperbaiki batas-batasnya.) .

Pendek kata, Derrida menilai bahwa kata "destruction" tidak cocok untuk digunakan sebagai terjemahan "destruktion," tapi lebih tepat jika digunakan menerjemahkan kata “demolition" menurut pemikiran Friedrich Nietzsche (1844-1900). Oleh sebab itu, Derrida urung menggunakan kata "destruction," kemudian ia berhasil menemukan kata di dalam kamus Prancis: "déconstruction" yang dinilai cukup memadai untuk menyampaikan pemikirannya. ${ }^{14}$

Karena kata "déconstruction" hanya sampai pada tataran "cukup memadai" atau belum bisa menggambarkan pemikiran Derrida secara utuh, maka menerjemahkannya ke dalam bahasa Jepang adalah sebuah keniscayaan. Yang perlu diingat adalah kata "déconstruction" tidak bisa diterjemahkan secara langsung dengan menggunakan kamus bahasa Prancis. ${ }^{15}$ Inilah pangkal dari semua kekeliruan yang terjadi selama ini. Maka jelas dengan sendirinya bahwa menerjemahkan kata "dekonstruksi" ke dalam bahasa apapun adalah sebuah keniscayaan, tapi kita tidak dapat memahami arti dari kata tersebut berdasarkan arti yang ditemukan pada kamus. Untuk itu pada paragraf selanjutnya di dalam suratnya, Derrida menunjukkan beberapa kekeliruan terhadap dekonstruksi.

Dekonstruksi sering dikaitkan dengan Strukturalisme oleh mereka yang memahaminya dengan menggunakan kamus. Padahal, dekonstruksi tidak hanya sekedar meninjau kembali apa yang tampak dipermukaan untuk menyingkapkan selubung metafisika yang ada dibaliknya, tapi juga mengguncangkan dasar dari struktur yang membangun sebuah proposisi (anti-strukturalis). Pendek kata, dekonstruksi bukanlah strukturalisme maupun anti-strukturalisme. Karena sesungguhnya dekonstruksi berada pada ambiguitas antara strukturalis dan anti-strukturalis. Dan di Amerika terlanjur dijuluki sebagai poststrukturalisme. ${ }^{16}$

\footnotetext{
${ }^{14}$ Derrida, Jacques. Letter to a Japanese Friend. h. 1-2.

${ }^{15}$ Arti kata "déconstruction" menurut kamus adalah: "menyusun ulang bangunan kata pada sebuah kalimat."

${ }^{16}$ Derrida, Jacques. Letter to a Japanese Friend. h. 2-3.
} 
Dekonstruksi juga bukan sebuah metode analisis ataupun sebuah metode kritik. Bukan sebuah metode analisis, karena dekonstruksi tidak bertujuan untuk mencari kebenaran utuh atau elemen terdasar dari dunia. Bukan juga sebuah metode kritik, karena justru metode kritik, seperti pada pemikiran Immanuel Kant (1724-1804), merupakan salah satu objek dari dekonstruksi. ${ }^{17}$ Secara lugas dapat dikatakan bahwa dekonstruksi tidak dapat dipahami sebagai sebuah metode apapun. Sebagai contoh: metode membaca atau menafsirkan sebuah literatur. Karena dekonstruksi bukanlah sebuah "alat" atau bahkan bukan sebuah tindakan praktis dalam oposisi biner aktif/pasif. Tepatnya, dekonstruksi adalah sebuah peristiwa (event) yang tidak memerlukan tindakan-aktif atau inisiatif seseorang atau kelompok orang yang dimotivasi oleh sebuah refleksi (penyadaran) diri. Dekonstruksi hanyalah sebuah penyingkapan bahwa segala sesuatu yang disadari oleh manusia--termasuk pemahaman terhadap dekonstruksi itu sendiri--akan mendekonstruksikan dirinya sendiri tanpa bantuan siapapun dan apapun. ${ }^{18}$ Dengan perkataan lain, dekonstruksi adalah sebuah penghancuran, jika bisa dikatakan demikian, tapi penghancuran yang berlangsung secara alamiah, tanpa campur tangan siapapun dan apapun. Namun dekonstruksi juga bukan sebuah penghancuran terhadap ontologi filsafat Barat, sebagaimana pada pemikiran Heidegger, dengan tujuan untuk membangun sebuah ontologi baru sebagai pengganti yang lama. ${ }^{19}$ Karena proposisi yang dibangun berdasarkan metafisika kehadiran tidak perlu untuk dihancurkan dari luar dirinya. Sebaliknya, proposisi tersebut akan menghancurkan dirinya sendiri untuk mendorong proposisi yang-lain yang juga akan menghancurkan dirinya (otodekonstruksi).

Kenyataan bahwa "dekonstruksi" tidak dapat didefinisikan sebenarnya merupakan penyingkapan dari bangunan teks yang memiliki potensi untuk mendekonstruksikan dirinya sendiri (oto-dekonstruksi). Di dalam Of Grammatology (1967) Derrida melakukan peninjauan kembali terhadap pemikiran filsafat Barat mengenai kesatuan antara teks dan pemikiran manusia untuk menyatakan bahwa terdapat jarak antara teks di satu sisi dan pemikiran manusia di sisi lainnya. ${ }^{20}$ Alhasil, kita tidak akan pernah bisa

\footnotetext{
${ }^{17}$ Derrida, Jacques. Letter to a Japanese Friend. h. 3.

${ }^{18}$ Derrida, Jacques. Letter to a Japanese Friend. h. 3-4.

${ }^{19}$ Derrida, Jacques. Letter to a Japanese Friend. h. 4.

${ }^{20}$ Derrida, Jacques. Letter to a Japanese Friend h. 4.
} 
mengucapkan dan menuliskan sebuah pemikiran dalam definisi yang ajek. Contohnya adalah: pemikiran tentang dekonstruksi itu sendiri. Sehingga dalam kerangka dekonstruksi penolakan terhadap "S adalah P" bisa juga disebutkan sebagai penolakan terhadap "dekonstrusk adalah ...”.

Dengan demikian, "dekonstruksi" tidak lebih dari sebuah teks yang memiliki karakteristik yang sama dengan teks pada umumnya, yaitu: diucapkan atau dituliskan dalam rantai-substitusi dengan teks lainnya. Sehingga dekonstruksi bisa diucapkan atau dituliskan dengan kata lain dalam bahasa Prancis atau dalam bahasa yang lain. Karena dekonstruksi tidak dapat dikurung dalam sebuah kata atau kalimat secara utuh.

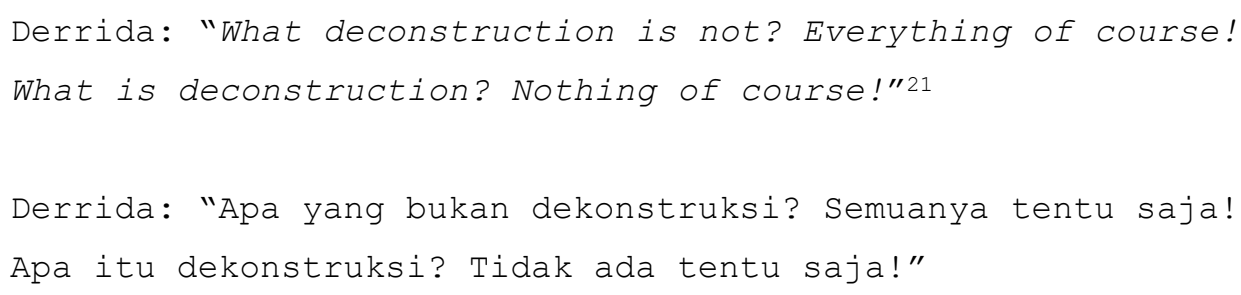

Akhir kata dalam suratnya kepada Izutsu, Derrida menyimpulkan bahwa menerjemahkan kata "dekonstruksi" ke dalam bahasa Jepang merupakan sebuah hal yang memungkinkan untuk dilakukan. Dan Izutsu tidak perlu mengikuti definisi yang terdapat dalam kamus bahasa Prancis. Mengingat "dekonstruksi" itu sendiri hanyalah sebuah kata yang dapat digantikan oleh kata dari bahasa lain dalam sebuah rantaisubstitusi. Izutsu hanya perlu untuk menerjemahkannya menjadi lebih indah, sebagaimana menerjemahkan sebuah puisi. ${ }^{22}$

Maka jelas dengan sendirinya bahwa dekonstruksi tidak dapat di "kurung" oleh teks apapun, bahkan "dekonstruksi" itu sendiri bukanlah nama atau sebutan yang tepat. Dekonstruksi juga menggambarkan kenyataan bahwa dunia tidak dapat diucapkan atau dituliskan secara utuh di dalam teks. Alhasil, dekonstruksi sebagai sebuah peristiwa tidak dapat diucapkan atau dituliskan secara utuh. Ia selalu terbuka untuk diucapkan atau dituliskan dengan teks yang-lain dalam berbagai bahasa.

\footnotetext{
21 Derrida, Jacques. Letter to a Japanese Friend. h. 5.

22 Derrida, Jacques. Letter to a Japanese Friend. h. 5.
} 


\section{Derrida tentang Teks}

Pemikiran Derrida tentang teks bertolak belakang dengan tradisi pemikiran filsafat Barat (epoch). Epoch menyatakan bahwa bahasa lisan merupakan representasi utuh dari Logos, sehingga kebenaran utuh tentang dunia merupakan sebuah kemustahilan. Karenanya, epoch menempatkan lisan sebagai yang-primer atau interioritas dari bahasa, sedangkan tulisan ditempatkan sebagai yang-sekunder atau eksterioritas dari bahasa (bandingkan dengan "The Outside and the Inside" dalam Of Grammatology, hal. 3044). Meskipun pemikiran epoch tersebut mendapat tantangan dari ahli bahasa kontemporer asal Prancis bernama André Martinet (1908-1999) dengan membalikkan oposisi biner antara lisan/tulisan dengan menyatakan bahwa tulisan lebih primer dibanding lisan, karena telah berperan penting dalam melestarikan bahasa, ${ }^{23}$ tapi Derrida dengan dekonstruksinya tidak pernah bermaksud untuk membalikkan oposisi biner dengan menempatkan bahasa tulisan sebagai yang-primer terhadap lisan.

Sebaliknya, ia hendak keluar dari cakrawala oposisi biner tersebut dengan menyatakan bahwa: lisan dan tulisan diikat secara alamiah oleh bahasa itu sendiri. ${ }^{24}$ Pendek kata, keduanya, baik lisan dan tulisan, merupakan eksterioritas dari bahasa pada dirinya sendiri. Maka jelas dengan sendirinya bahwa bagi epoch "bahasa" pada dirinya sendiri disebut sebagai lisan yang kemudian melahirkan tulisan, sedangkan di mata Derrida terdapat sebuah "jejak" (Inggris: trace) yang menyatukan keduanya (lisan dan tulisan). ${ }^{25}$ Namun Derrida tidak menyatakan “jejak” sebagai origin dari bahasa. Karena jika demikian ia tetap berada dalam cakrawala oposisi biner yang berpangkal pada origin atau kebenaran utuh yang disebut sebagai Being. Atau dengan istilah lain, ia hendak membawa wacana filosofis keluar dari jerat onto-teologi. Maka, “jejak” yang dimaksudkan tidak lain adalah différance atau permainan dari penundaan terhadap makna dan permainan dari perbedaan terhadap kesatuan teks. ${ }^{26}$ Walhasil, bukan hanya apa diucapkan, tapi juga apa yang dituliskan adalah eksterioritas bahasa itu sendiri. Sedangkan bahasa itu sendiri adalah permainan atau différance.

${ }^{23}$ Derrida, Jacques (1997). Of Grammatology. Penerj. Gayatri Chakravorty Spivak. Baltimore: Johns Hopkins University Press. h. 31.

${ }^{24}$ Derrida, Jacques. Of Grammatology. h. 35.

${ }^{25}$ Derrida, Jacques. Of Grammatology. h. 47.

${ }^{26}$ Derrida, Jacques. Of Grammatology. h. 65. 


\section{Kesimpulan}

Seluruh sejarah pemikiran filsafat Barat diwarnai dengan segala usaha untuk menjelaskan dunia secara utuh melalui teks berdasarkan keyakinan bahwa dunia telah memberikan diri seutuhnya agar dapat dipahami oleh logika manusia. Sehingga manusia niscaya dapat memahami dunia secara jelas atau jernih. Di mata Derrida, tradisi pemikiran filsafat Barat tersebut berada dalam jerat onto-teologi atau metafisika kehadiran yang menyatakan bahwa kebenaran utuh tentang dunia ada atau hadir-layaknya sebuah entitas--di luar teks. Contohnya dapat ditemukan dalam pemikiran dari filsuf Jerman bernama Immanuel Kant (1724-1808) tentang Das Ding an Sich (benda pada dirinya sendiri) yang tidak bisa dipahami oleh manusia.

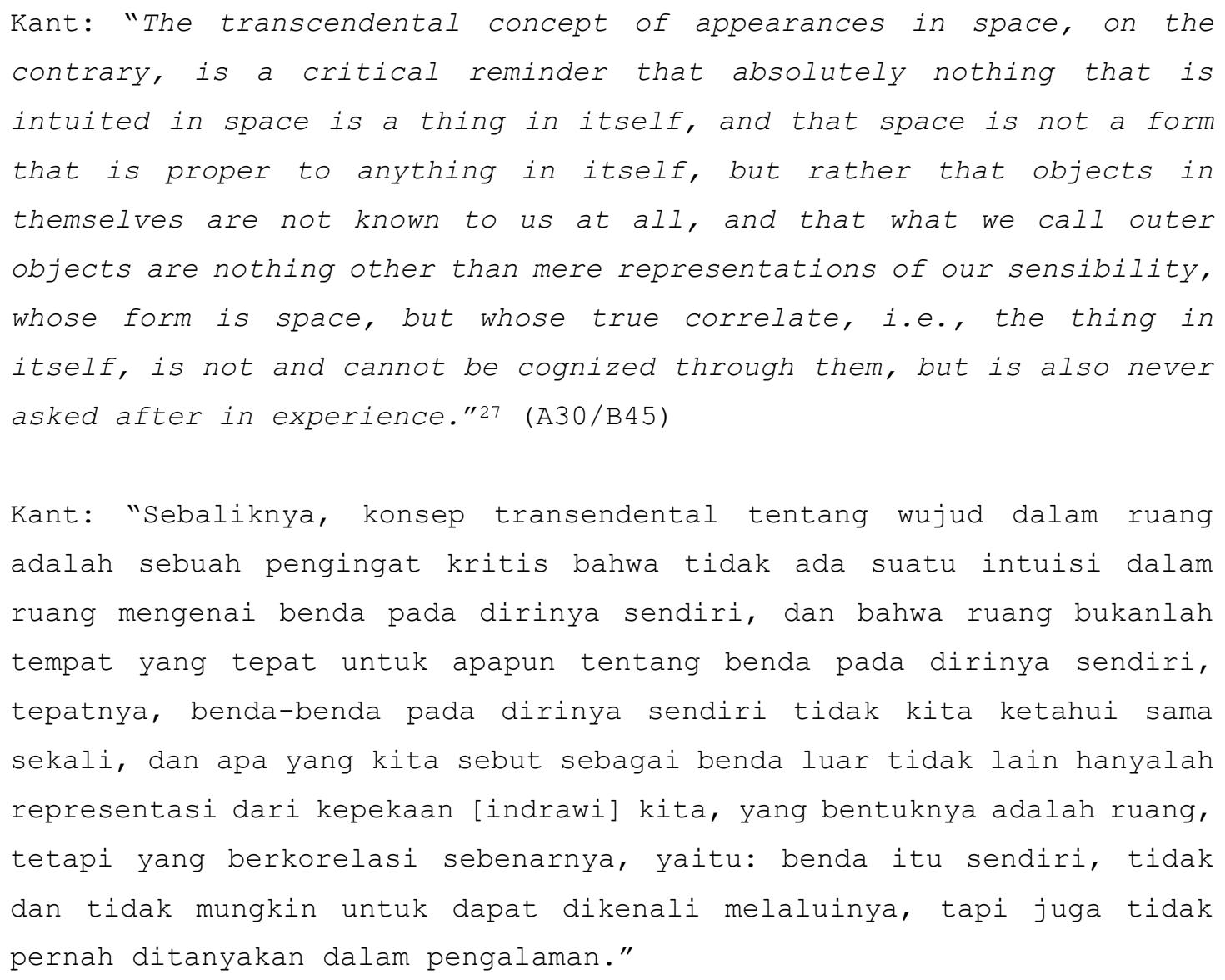

Kutipan di atas menjelaskan bahwa kebenaran utuh tentang benda-pada-dirinya-sendiri tidak dapat dipahami oleh manusia. Namun bukan berarti "kebenaran-utuh" itu tidak

${ }^{27}$ Kant, Immanuel (1998). Critique of Pure Reason. Penerj. Paul Guyer dan Allen W. Wood. Cambridge: Cambridge University Press. h. 161-162. 
ada. Karena Kant hanya menyatakan bahwa: keberadaan dari kebenaran-utuh tentang dunia atau benda tidak dapat dijangkau oleh seluruh keberadaan manusia. Pendek kata, kebenaran utuh itu ada, tapi manusia tidak dapat menjangkaunya. Maka jelas dengan sendirinya bahwa Kant tetap berada dalam jerat metafisika kehadiran. Karena ia telah menyatakan "kebenaran-utuh" sebagai kehadiran seperti sebuah entitas (being). Meski tidak terjangkau oleh manusia.

Berdasarkan fakta bahwa seluruh pemikiran filsafat Barat berada pada jerat metafisika kehadiran, maka Derrida hendak membawa kita keluar dari jerat tersebut dengan menyatakan bahwa tidak ada kehadiran lain di luar teks (il n'y a pas de hors-texte). ${ }^{28}$ Alhasil, yang disebut sebagai "kebenaran utuh" atau Being oleh tradisi filsafat Barat tidak lebih dari sekadar teks belaka. Dan di antara dunia dan teks tidak ada kehadiran dari sebuah "kebenaran utuh." Manusia hanya berhadapan dengan dunia yang tidak dikenali oleh logika selain oleh pencerapan indra. Namun dengan permainan dari penundaan makna tentang dunia yang ada di hadapannya dan permainan perbedaan antara teks yang satu dengan teks lainnya, maka manusia dapat mengucapkan dan menuliskan dunia agar dapat dipahami oleh logika. Pendek kata, bagi Derrida, kita hanya memiliki teks yang merupakan objektifikasi atau hasil dari konversi pengalaman indrawi di dalam dunia. Dengan memiliki teks, manusia tidak serta-merta memiliki dunia secara utuh, dan lagi, teks tidak merujuk pada keberadaan dari kebenaran utuh tentang dunia. Karena teks menunjukkan ke-tidak-hadiran kebenaran utuh tentang dunia, dan ke-tidak-hadiran ini telah diisi oleh permainan penundaan dan perbedaan, maka dunia dapat diucapkan dan dituliskan secara bebas. Tanpa batas.

Namun secara bersamaan, penyingkapan yang dilakukan oleh Derrida terhadap jerat metafisika kehadiran telah mengubah wajah filsafat secara radikal. Filsafat dalam cakrawala Derrida tidak lagi dipandang sebagai jalan untuk membicarakan dunia secara mendalam dan jernih untuk menemukan kebenarannya secara utuh. Filsafat dalam pemikiran Derrida tidak lebih dari sebuah jalan untuk membicarakan dunia secara bebas melalui berbagai sudut pandang atau keragaman literatur. Dengan perkataan lain, Derrida telah membebaskan filsafat dari tugas untuk menjelaskan dunia secara utuh. Hasilnya, filsafat tidak lain adalah sebuah literatur tentang dunia.

${ }^{28}$ Derrida, Jacques. Of Grammatology. h. 158. 


\section{DAFTAR PUSTAKA}

Derrida, Jacques.1988. Letter to a Japanese Friend dalam Derrida and Différance. Evanston: Northwestern University Press.

, Jacques. 1997. Of Grammatology. Baltimore: Johns Hopkins University Press. , Jacques.1973. Speech and Phenomena. Evanston: Northwestern University Press. , Jacques. 2001. Writing and Difference. London: Routledge Classics.

Husserl, Edmund. 2001. Logical Investigations Volume I. London dan New York: Routledge.

Heidegger, Martin. 1996. Being and Time. Albany: State University of New York Press.

Kant, Immanuel. 1998. Critique of Pure Reason. Cambridge: Cambridge University Press. 